\title{
Riverbank Erosional Features in the Stanley Pool of the Congo River and Some Geotechnical Classifications of the Sands
}

\author{
Guy Dieudonne Moukandi N'Kaya ${ }^{1}$, Narcisse Malanda' ${ }^{1}$, Olivier Florent Essouli², \\ Bernard Mabiala ${ }^{1}$, Alain Laraque ${ }^{3}$
}

\begin{abstract}
${ }^{1}$ Mechanical, Energy and Engineering Laboratory/UNESCO Chair in Engineering Sciences/Ecole Nationale Supérieure Polytechnique, Marien Ngouabi University, Brazzaville, Congo

${ }^{2}$ Geosciences Laboratory, Faculty of Sciences and Technology, Marien Ngouabi University, Brazzaville, Congo

${ }^{3}$ Geosciences Environment Toulouse-UMR 5563 of CNRS, UMR 234 of Institute of Research for Development/Paul Sabatier University, Montpellier, France

Email: *guymoukandi@yahoo.fr
\end{abstract}

How to cite this paper: Moukandi N'Kaya, G. D., Malanda, N., Essouli, O. F., Mabiala, B., \& Laraque, A. (2019). Riverbank Erosional Features in the Stanley Pool of the Congo River and Some Geotechnical Classifications of the Sands. Journal of Geoscience and Environment Protection, 7, 152-167. https://doi.org/10.4236/gep.2019.75014

Received: March 28, 2019

Accepted: May 27, 2019

Published: May 30, 2019

Copyright (c) 2019 by author(s) and Scientific Research Publishing Inc. This work is licensed under the Creative Commons Attribution International License (CC BY 4.0).

http://creativecommons.org/licenses/by/4.0/

\begin{abstract}
The Stanley Pool, an almost circular island about thirty kilometers in diameter, crossed by the Congo River, is subject to diversified erosion of its riverbanks. This study highlights description using geotechnical particle size distribution analysis of soils of the shoreline that make up the shoreline. Three critical areas of the island were examined to characterize the origins of these erosion phenomena. The results obtained show that the soil materials are mostly sands with very fine or fine grains characteristic of very unstable soils. The morpho-sedimentological characteristics of the areas studied show that these soils are plastic (with a Plasticity Index between 15 percent and 19 percent). The presence of water, action of currents or groundwater flow easily destabilize the materials that make up the riverbank and cause the fines to creep (Collapse of sandy riverbanks, Landslide of sandy riverbanks, ...).
\end{abstract}

\section{Keywords}

Erosion, Riverbanks, Congo River, Stanley Pool, Geotechnical Analysis, Particle Size Distribution

\section{Introduction}

The functioning of a watercourse is based on a relative balance between solid and liquid flows; the imbalance of one of these parameters will lead to a readjustment of the geometry of the watercourse (Casagli et al., 1999; Dapporto et al., 
2001; Thorne \& Tovey, 1981; Wood et al., 2001). These morphological readjustments include riverbed sinking and/or riverbank erosion (Casagli et al., 1999; Couper \& Maddock, 2001; Dapporto et al., 2001; Lawler, 1992; Hamel et al., 2013). Since the last century $\left(20^{\text {th }}\right)$, the Congo River has experienced these hydrological disturbances in some places along its course. At the Stanley Pool, the Congo River has always eroded its banks to which its initial surface area gradually falls in favor of the waters, thus causing sandbanks at the ports of Brazzaville. This situation is undoubtedly also caused by the rapid, anarchic and progressive urbanization of the metropolises (Kinshasa and Brazzaville), currently putting the Congo in a transitional phase, a period of instability, i.e. in search of a new balance.

This situation is obviously accompanied by upheavals, one of the expressions of which is the accentuation of erosion phenomena that have been revealing themselves significantly for decades. The knowledge of these erosion phenomena is studied from the calculations of the material flows transported by the Congo River. These flows are calculated at their main hydrometric stations (Moukolo et al., 1993; Probst et al., 1992; Orange et al., 1995) or estimated at their confluences from a single annual sampling (Gaillardet et al., 1995). The first annual balances of flows from the Congo River, calculated from chronicles of monthly flows measured at the main stations and values representative of flows concerning uncontrolled downstream zones, were made (Laraque et al., 2009; Laraque et al., 2001). These studies have highlighted the roles of different physiographic units based on transport dynamics. Most of this work studied the downstream problem without taking into account all the processes of the river erosion phenomenon characterized by three stages: disintegration, transport and sedimentation.

This paper presents a first analysis of the erosion mechanisms of the riverbanks of the Congo River at the Stanley Pool.

Using geotechnical methods (particle size distribution, Atterberg limits and Shear tests), this work studies the factors of riverbank erosion in the Congo River at the Stanley Pool. Understanding the mechanisms of riverbank erosion and their spatial extent is fundamental for identifying riverbank control and management measures and watershed management.

\section{Materials and Methods}

\subsection{Study Area}

The Stanley Pool is a depression covering about thirty kilometers in diameter, emerging in the middle of the Congo River, at the north-eastern border end of the city of Brazzaville. The island is situated between the parallels $9^{\circ} \mathrm{N}$ and $14^{\circ} \mathrm{S}$ and the meridians $11^{\circ} \mathrm{E}$ and $31^{\circ} \mathrm{E}$, and presents as much by its shape, its relief, its geology, its climate, as by its vegetal cover, a generally concentric structure between the waters of the Congo River or central depression (Figure 1). The soils of the island are heterogeneous in its major part with regular soil stratifications. 


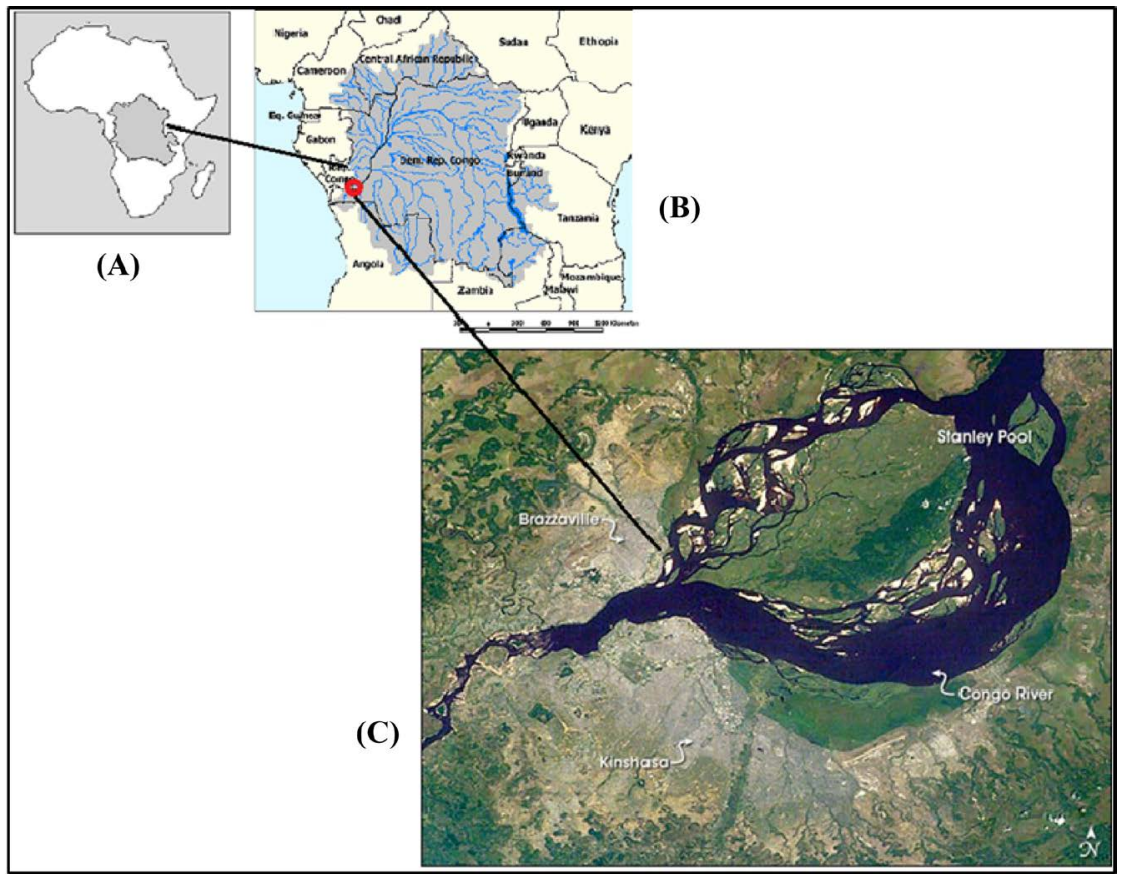

Figure 1. Location of the study site: (A) Location of the Congo River Basin inset on African (B) Drainage pattern of the Congo River Basin (CRB); (C) Stanley Pool.

These soils are classified as follows: Arab soil on the surface followed by silt and sand formations. However, towards the riverbanks, the soils encountered are sandy; sometimes silt sands or clayey silts are encountered.

The study area is subject to several phenomena due to the erosion of the riverbanks very diversified and which requires be analyzing and studying:

The sedimentation of suspended matter encountered on the channel (Organic matter in general) in large quantities and over hundreds of meters is undoubtedly due to the water erosion of the riverbanks and this prevents good navigation, although this is accentuated by the low water level of the river (Figure 2).

The golf phenomena observed on the shorelines of the shores sufficiently shows that this was also due to the water erosions of the riverbanks (Figure 3).

The undermining caused by the waves and the scouring of the water create crevasses enclosing part of the river bed (Figure 4 and Figure 5). These crevasses will develop many phenomena and hydraulic interactions which will inevitably lead to more accentuated deformations of the riverbanks in the zones of their manifestation.

Landslides that occurred at our passage (in December during the rainy season) further confirm that the riverbanks are unstable and therefore subject to potential water erosion (Figure 6 and Figure 7).

The uprooting of vegetation observed in certain places sufficiently shows the extent of damage caused by hydraulic and hydrological activity during the peaks at major river beds on the riverbanks (Figure 8 and Figure 9).

The degradation of the relief observed at certain embankments of the riverbanks (structure of the soil materials not very regular in its transverse stratification) 


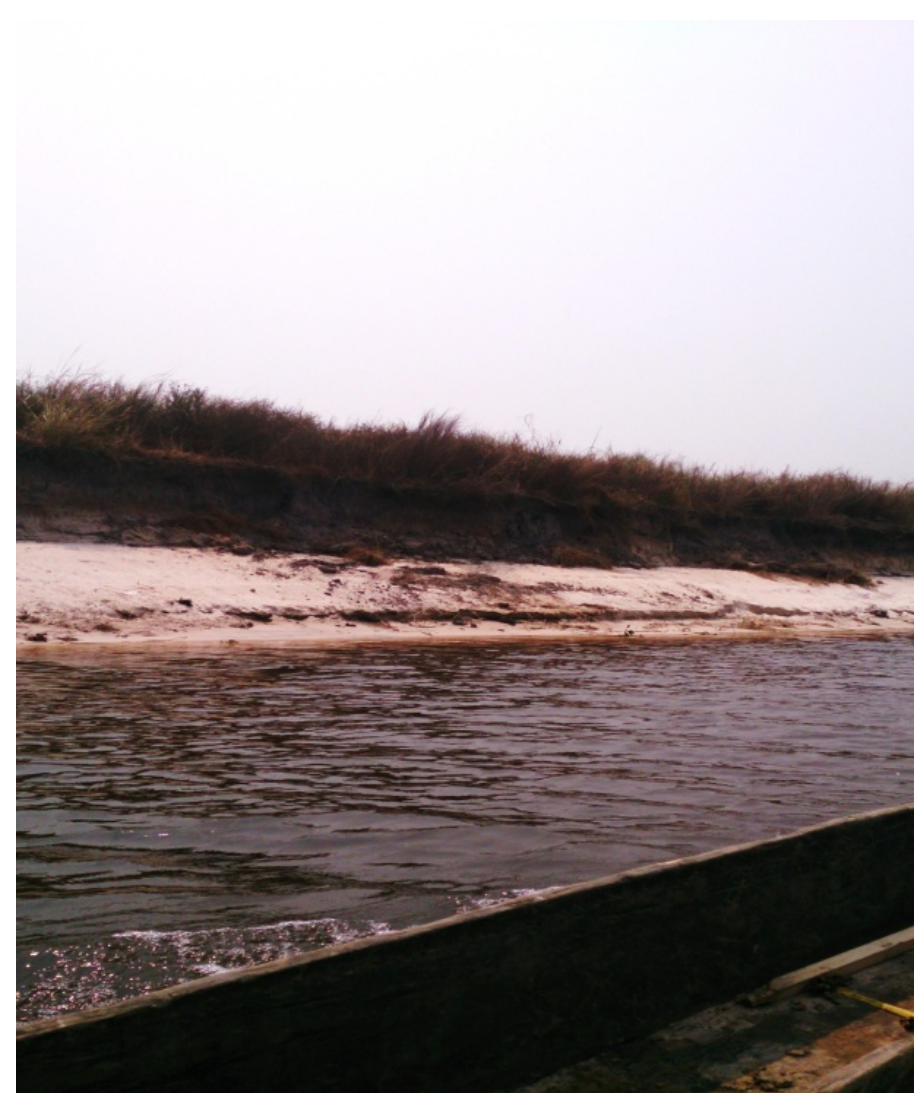

Figure 2. Sand deposit on a clay soil at the riverbank.

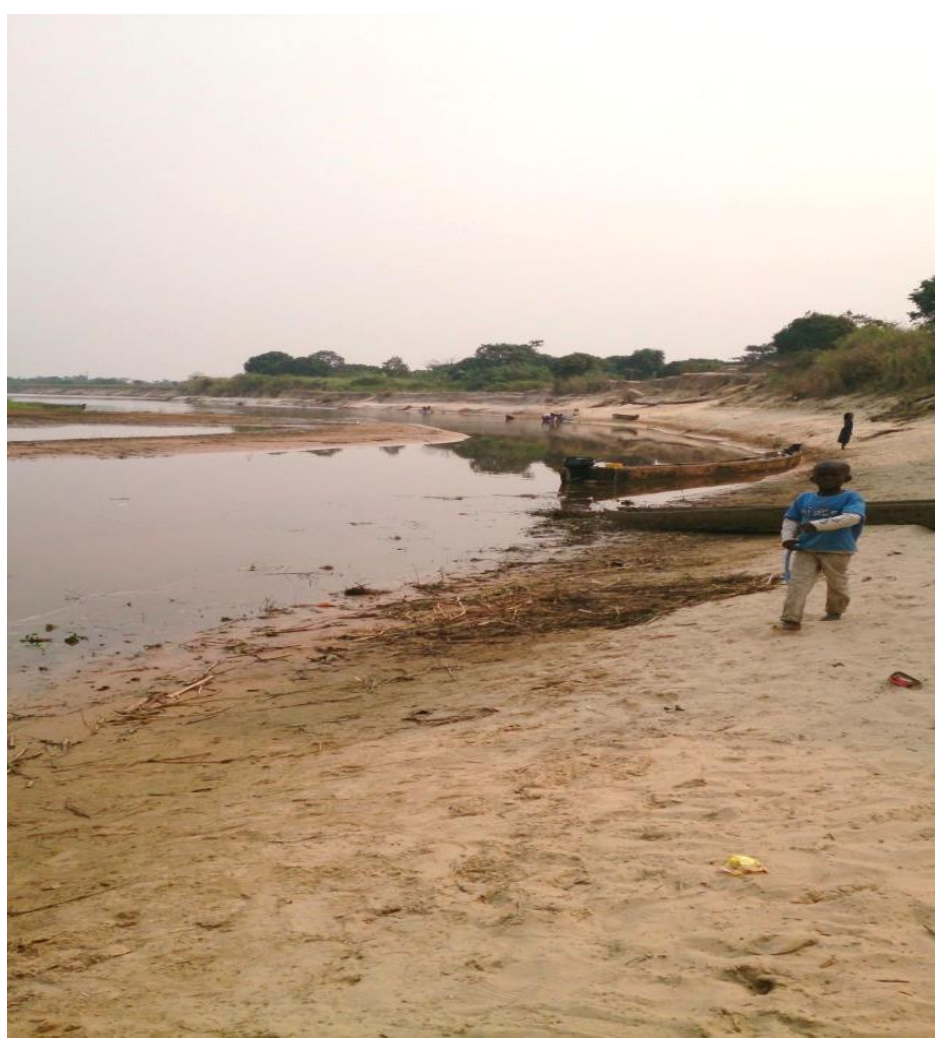

Figure 3. Golf courses caused by erosion on silt ground. 


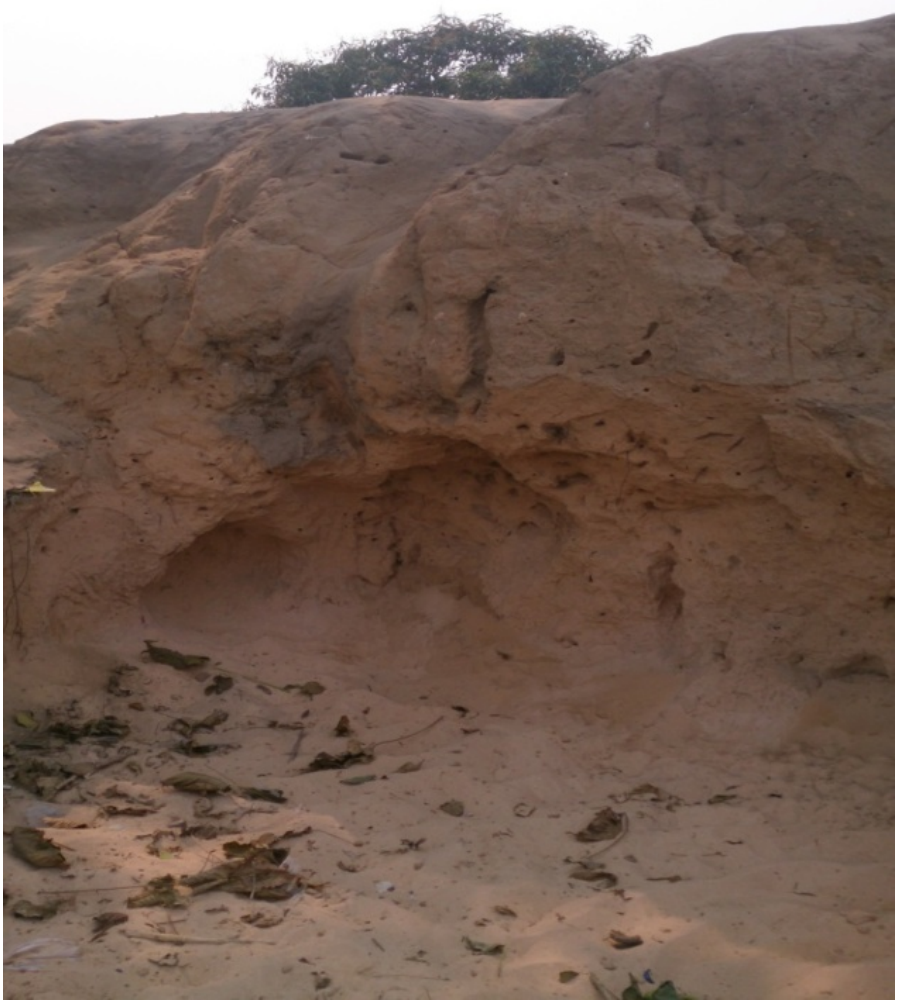

Figure 4. Escapement at the foot of the riverbank in a clay soil.

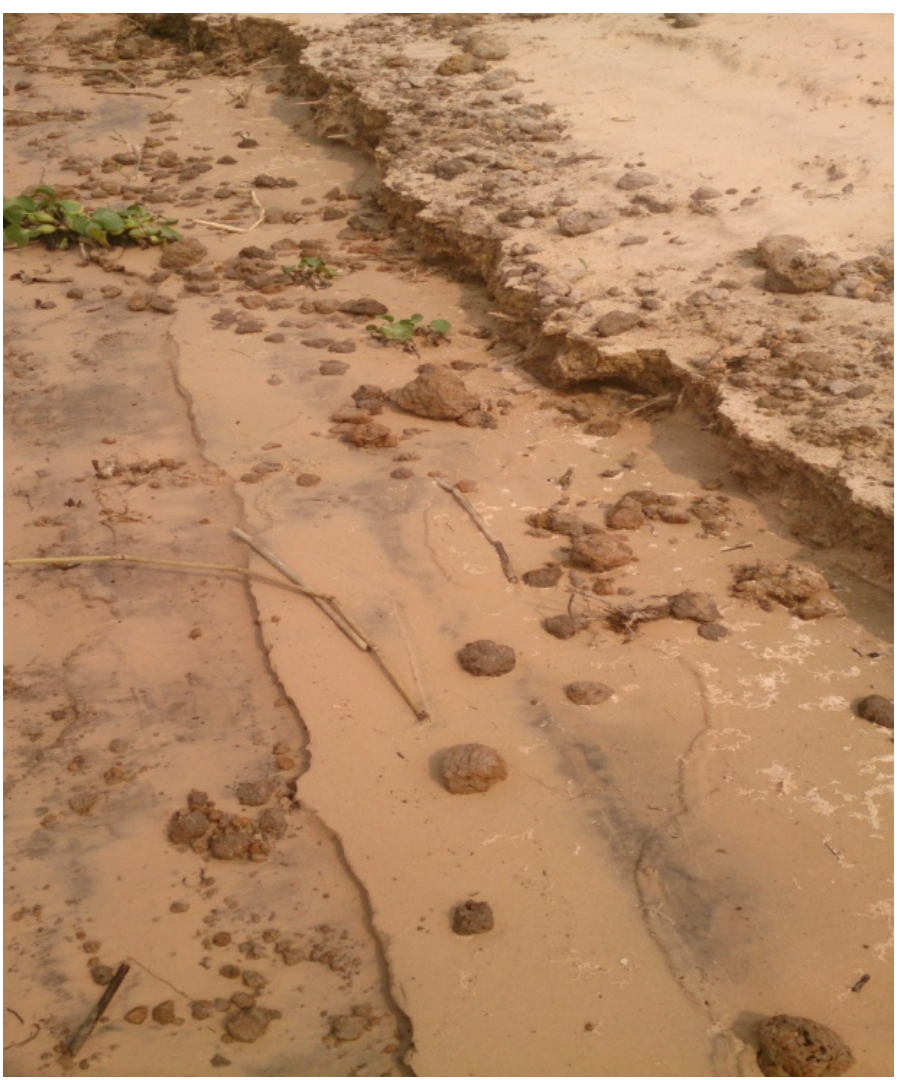

Figure 5. Surface erosion due to wave action. 


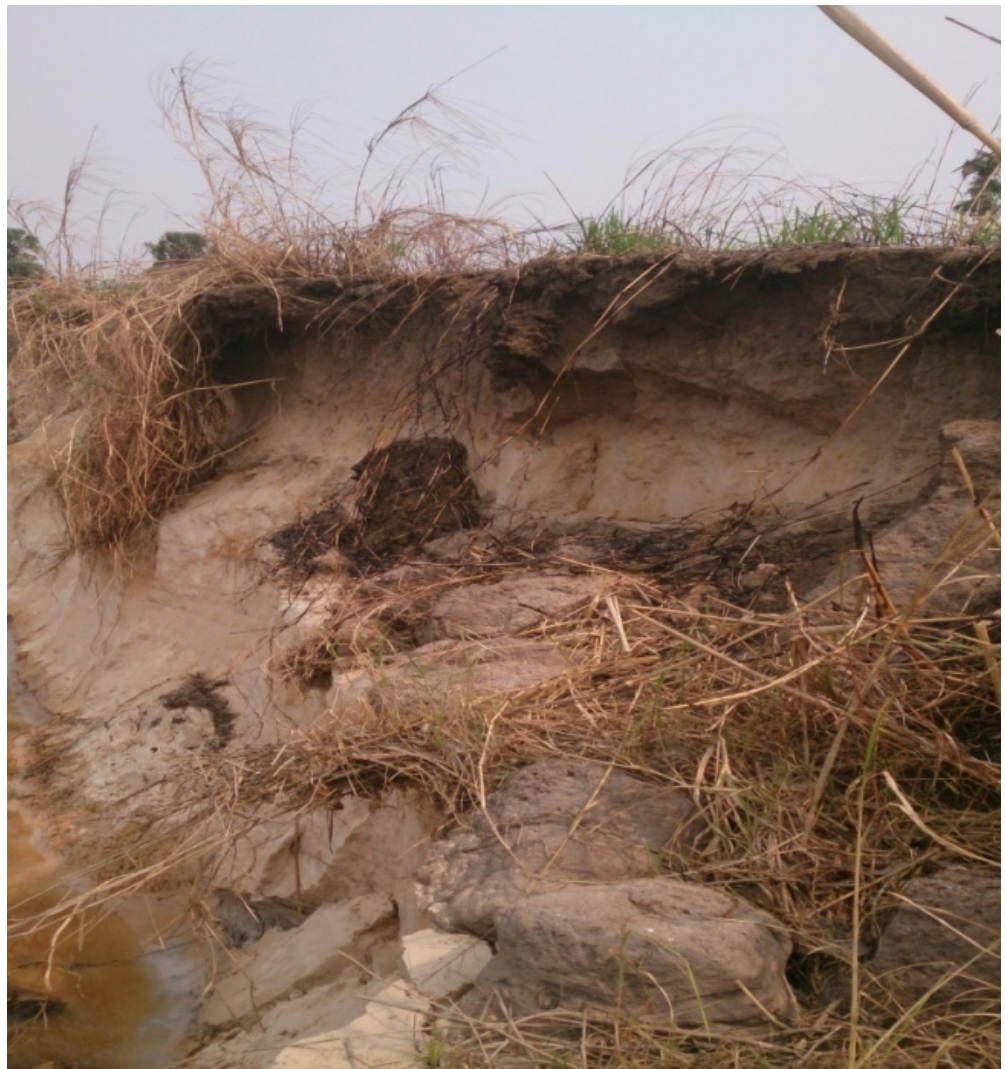

Figure 6. Collapse of sandy riverbanks.

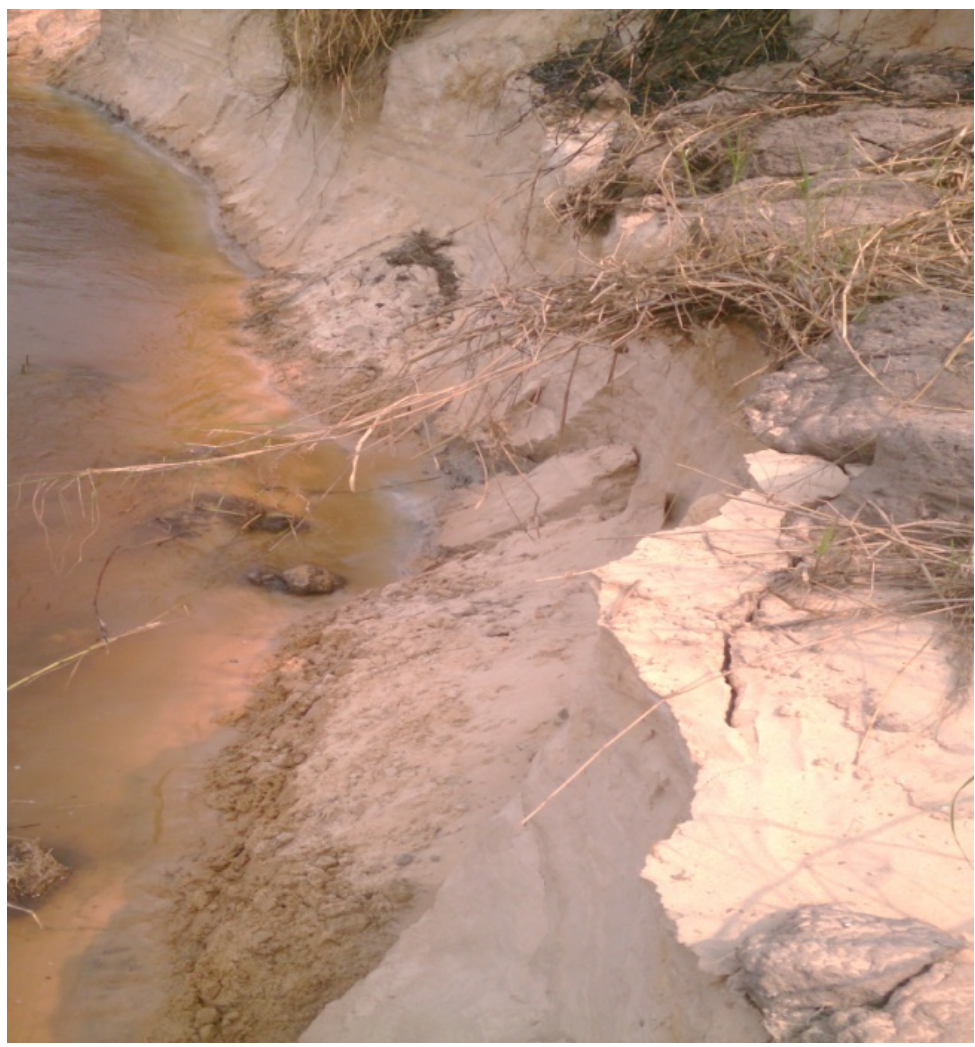

Figure 7. Landslide of sandy riverbanks. 


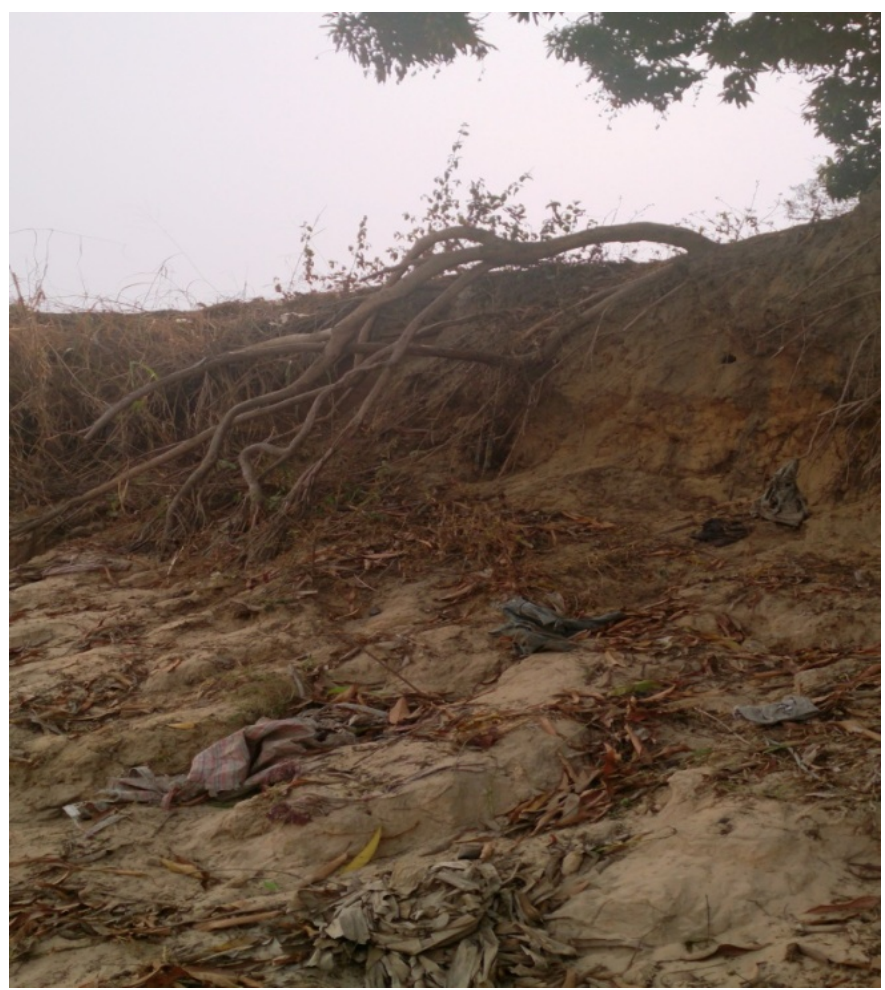

Figure 8. Sliding and scouring on silty soil.

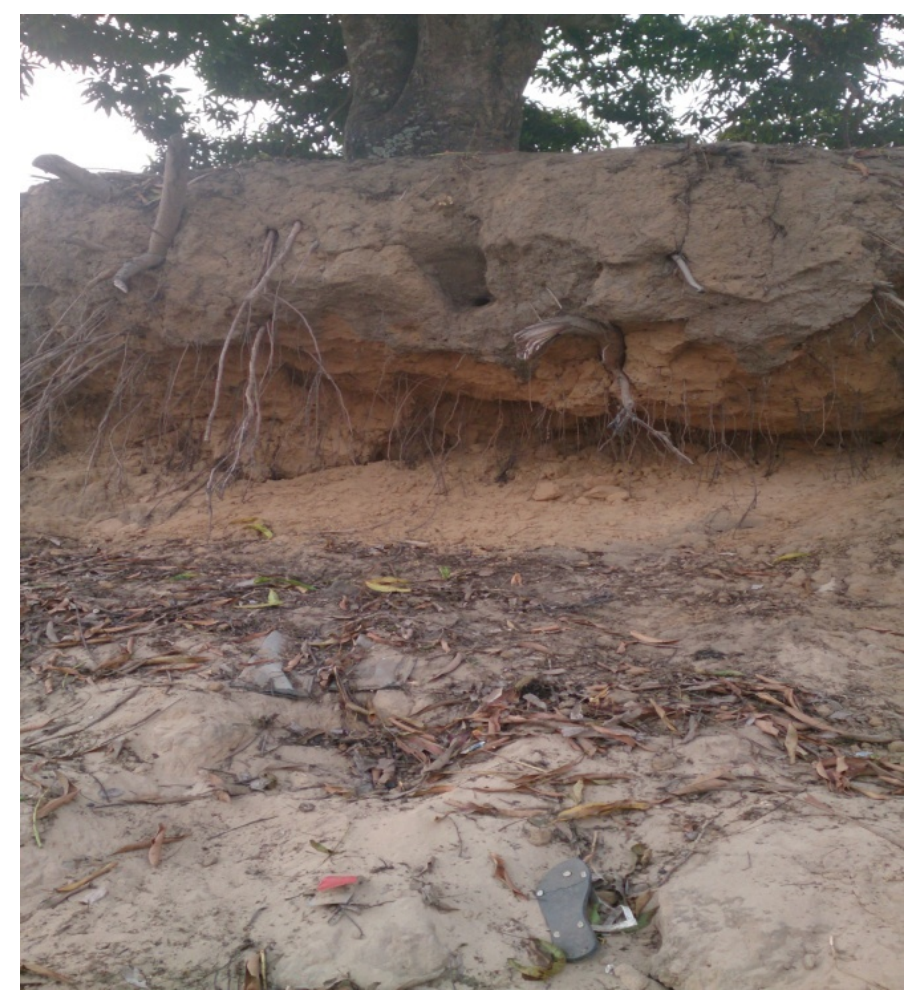

Figure 9. Scouring sequence of riverbanks causing landslides of silty soils.

makes it possible to understand that these riverbanks were subjected to the action of erosive phenomena (Figure 10 and Figure 11). 


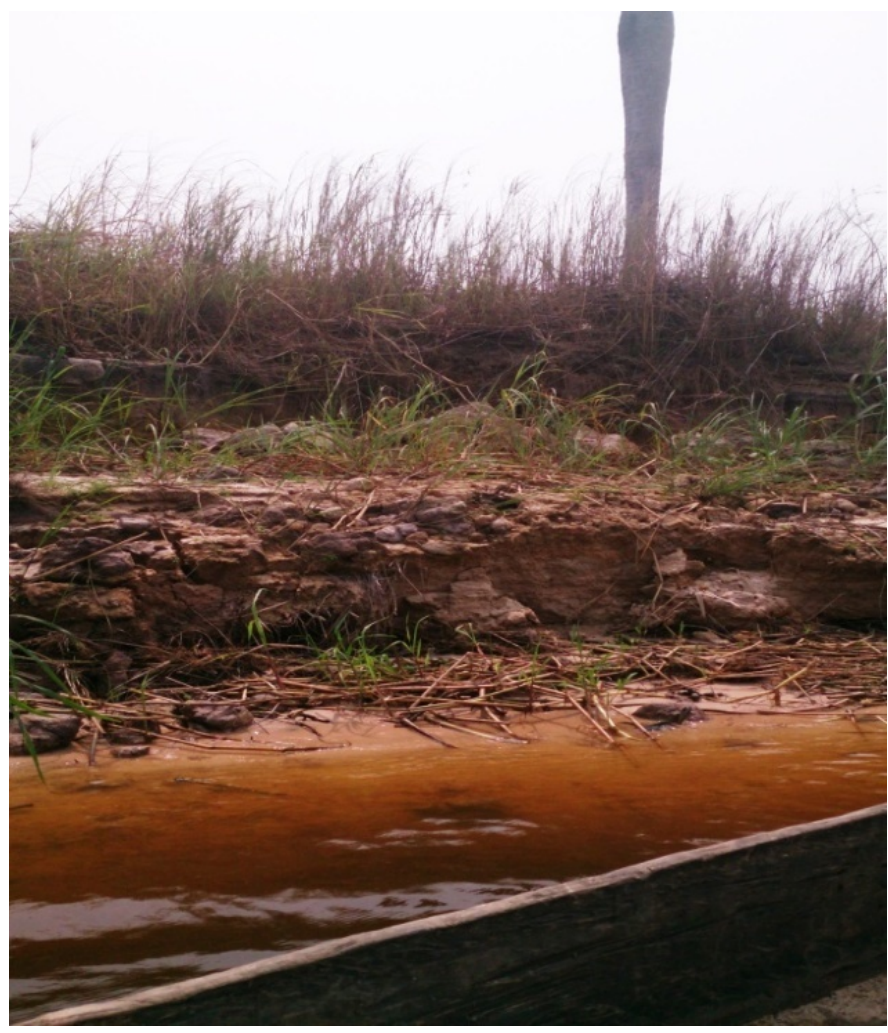

Figure 10. Erosion sequence on clay soil Erosion sequence on clay soil (Black line illustrates the first erosion sequence and the dashed line illustrates the second erosion sequence).

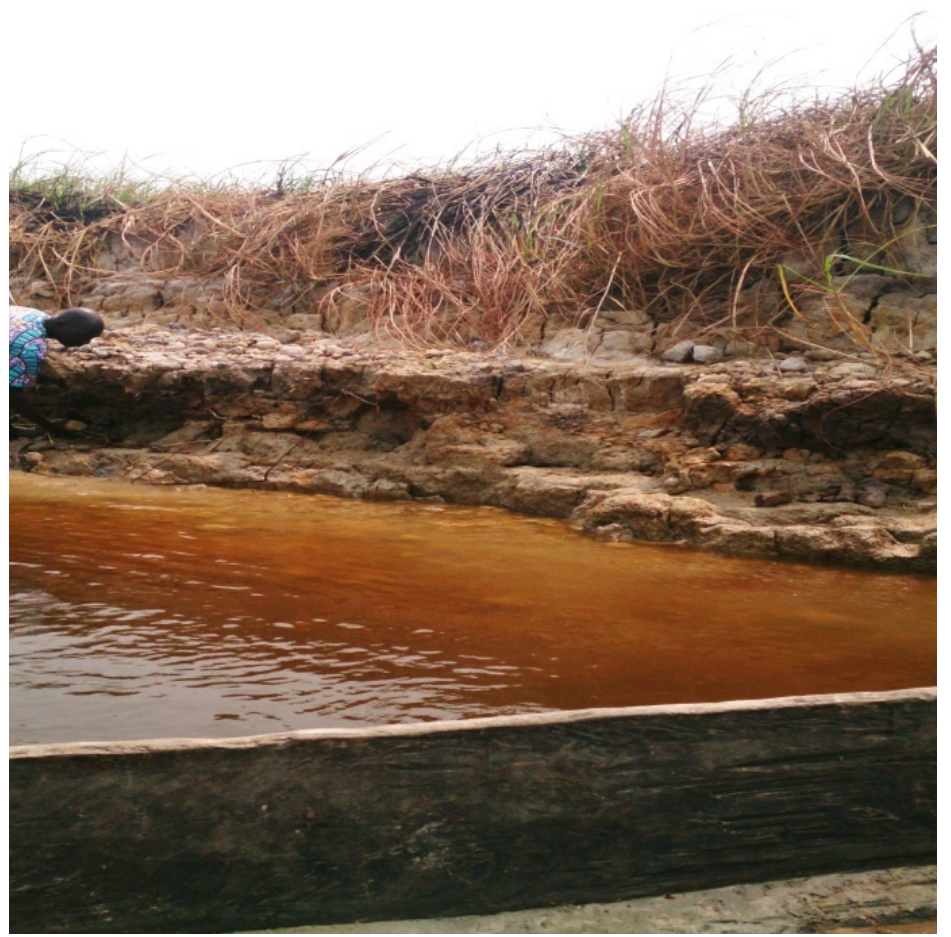

Figure 11. Erosion following desiccation of clayey soil. 


\subsection{Soil Sample Collection}

Three zones, qualified as critical zones, were selected to collect soil samples during field visits to the study area sites. Sampling was carried out during the low and high water seasons according to the hydrological cycle of the Congo River. These samples were subjected to laboratory analyses (particle size analysis, Atterberg Boundaries and shear tests). The installation of river activity control beacons at the edges of the riverbanks and the taking of measurements on secondary flows towards the shore were carried out.

All samples were collected on the surface; they are intact and undisturbed samples. For these collected samples, the following tests were performed:

\subsubsection{Particle Size Analysis}

Particle size analysis is performed on all material samples taken in the field. In order to separate the aggregates, mechanical grinding is first applied to all samples. No chemical pre-treatment is performed since the samples contain very little organic matter and sesquioxides. Mechanical screening (ASTM D422-63, 2007) separates the grains into 14 particle size classes ranging from very coarse sand $(\geq 2 \mathrm{~mm})$ to very fine sand $(\leq 63 \mu \mathrm{m})$. The use of a sedigraph allows the particle size distribution below $63 \mu \mathrm{m}$ to be established.

\subsubsection{Atterberg Boundaries}

The establishment of the Atterberg Boundaries allows the sensitivity of the material to variations in water content to be assessed. This sensitivity varies according to the particle size and mineralogy of the soil. The method makes it possible to establish the transition points between the solid, plastic or liquid state of a material. To establish the liquidity limit, the Casagrande cup method (ASTM D422-63, 2007) e2 is applied to all material samples. The plastic limit is determined by the coil test (ASTM D4318-00, 2000) performed on a subsample of the material prepared for the liquidity limit. The liquidity limit (LL) and plasticity limit (PL) results are used to establish the plasticity index (IP), defined by:

$$
\mathrm{IP}=\mathrm{LL}-\mathrm{PL}
$$

\subsubsection{Mechanical Erosion Resistance}

The mechanical strength of the material is determined using the Direct Shear Test (ASTM-D3080, 1998) applied to undisturbed samples. This test is expressed by the effective cohesion $\left(c^{\prime}\right)$ and the internal friction angle $(\varnothing)$. Cohesion is the force of attraction that unites particles to each other and ensures their physical coherence. The friction angle expresses the intergranular friction of the material. The mechanical strength is expressed by the Mohr-coulomb equation:

$$
\zeta=\sigma \tan (\varnothing)+c^{\prime}
$$

The aim here is not to highlight all the mechanical or chemical agents that cause or participate in the erosion process, but simply to highlight the significant causes of these disorders based on the results of the geotechnical approach; in other words, to highlight the configuration of the riverbanks, which themselves 
are linked to several elements, among others, the nature of the materials that make up the riverbanks. According to their type (clay, sand, silt, etc.), their particle size, their mixture and their arrangement, the consistency and cohesion varies.

\section{Results}

\subsection{Particle Size Analysis}

The majority of the results obtained in the three critical zones of the Stanley Pool show that the soil materials analyzed are sands with very fine grains because the fineness modulus (MF) is between 0.97 and 1.99; Since " $d$ " the smallest dimension of the aggregates is less than $0.5 \mathrm{~mm}$, these sands will be of class $0 / \mathrm{D}$, i.e. class $0 / 0.200$ to $0 / 0.5$. The D50 values are $0.130 \mathrm{~mm}, 0.230 \mathrm{~mm}$ and $0.280 \mathrm{~mm}$ respectively (Table 1 \& Figure 12).

Two of these samples (Samples 4 and 5 from zone 3 ) showed that the soils thus analyzed are a very fine material with a fairly high percentage of filler, the fineness modulus (MF) is equal to 0.469 , less than 0.8 . In addition, the percentage of sieves is greater than $50 \%$, hence the need to carry out Atterberg limits on these samples in order to better know its properties.

Table 1. Morpho-sedimentological characteristics of the study area riverbanks.

\begin{tabular}{|c|c|c|c|c|c|c|c|c|c|c|c|}
\hline \multirow{2}{*}{ Sample } & \multirow{2}{*}{$\begin{array}{l}\text { Type of } \\
\text { sediment }\end{array}$} & \multicolumn{5}{|c|}{ Particle size (\%) } & \multicolumn{3}{|c|}{ Atterberg Boundaries (\%) } & \multicolumn{2}{|c|}{$\begin{array}{c}\text { Shear } \\
\left(\mathrm{KPa} \text { et }{ }^{\circ}\right)\end{array}$} \\
\hline & & Sand & Silt & Clay & SC & D50 & LL & LP & PI & $C$ & $\varnothing$ \\
\hline 1 & Fine sands & 76.9 & 22 & 1.1 & 23.1 & 130 & & & & & \\
\hline 2 & Fine sands & 99.3 & 0.7 & 0 & 0.7 & 230 & & & & & \\
\hline 3 & Fine sands & 99.3 & 0.66 & 0.04 & 0.7 & 280 & & & & & \\
\hline 4 & Sandy clay & 43.9 & 12 & 44.1 & 56.1 & 68 & 31.4 & 16.6 & 15 & 13.87 & 10.34 \\
\hline 5 & Sandy clay & 43.6 & 7.1 & 49.3 & 56.4 & 60 & 31.5 & 12.7 & 19 & 17.96 & 8.28 \\
\hline
\end{tabular}

$\mathrm{SC}=$ percentage of silt and clay in the sample; D50 = median particle diameter of the sample $(\mu \mathrm{m}) ; \mathrm{LL}=\mathrm{li}$ quidity limits; LP = plastic limit; IP = plastic index; $C=$ effective cohesion; $\Phi=$ friction angle.

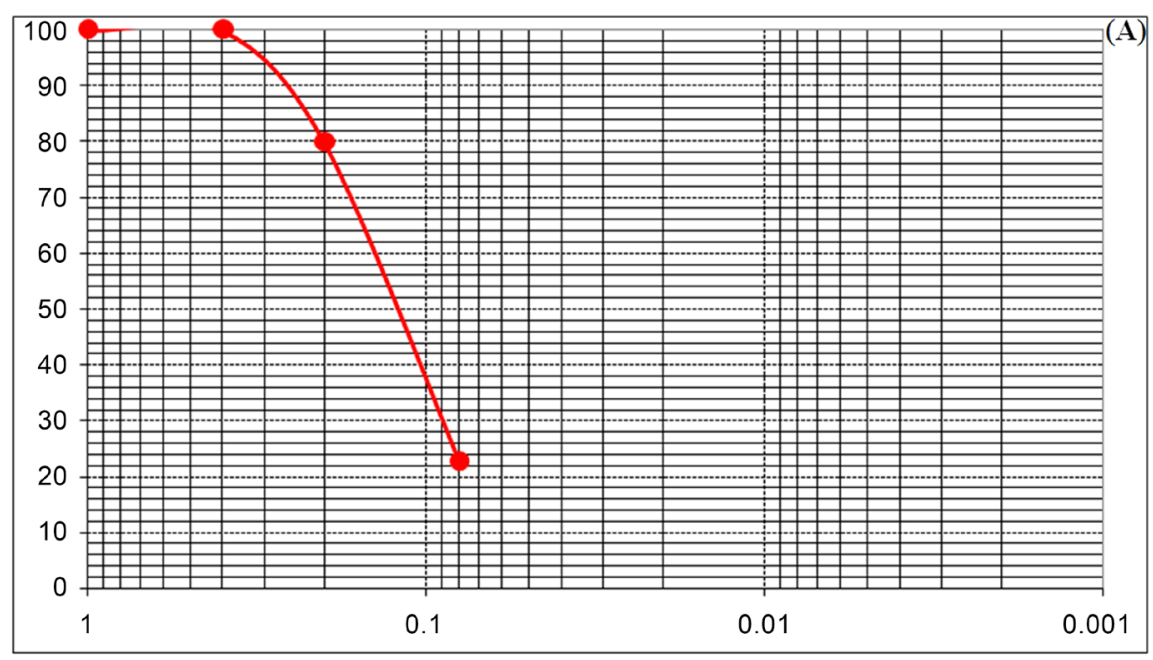



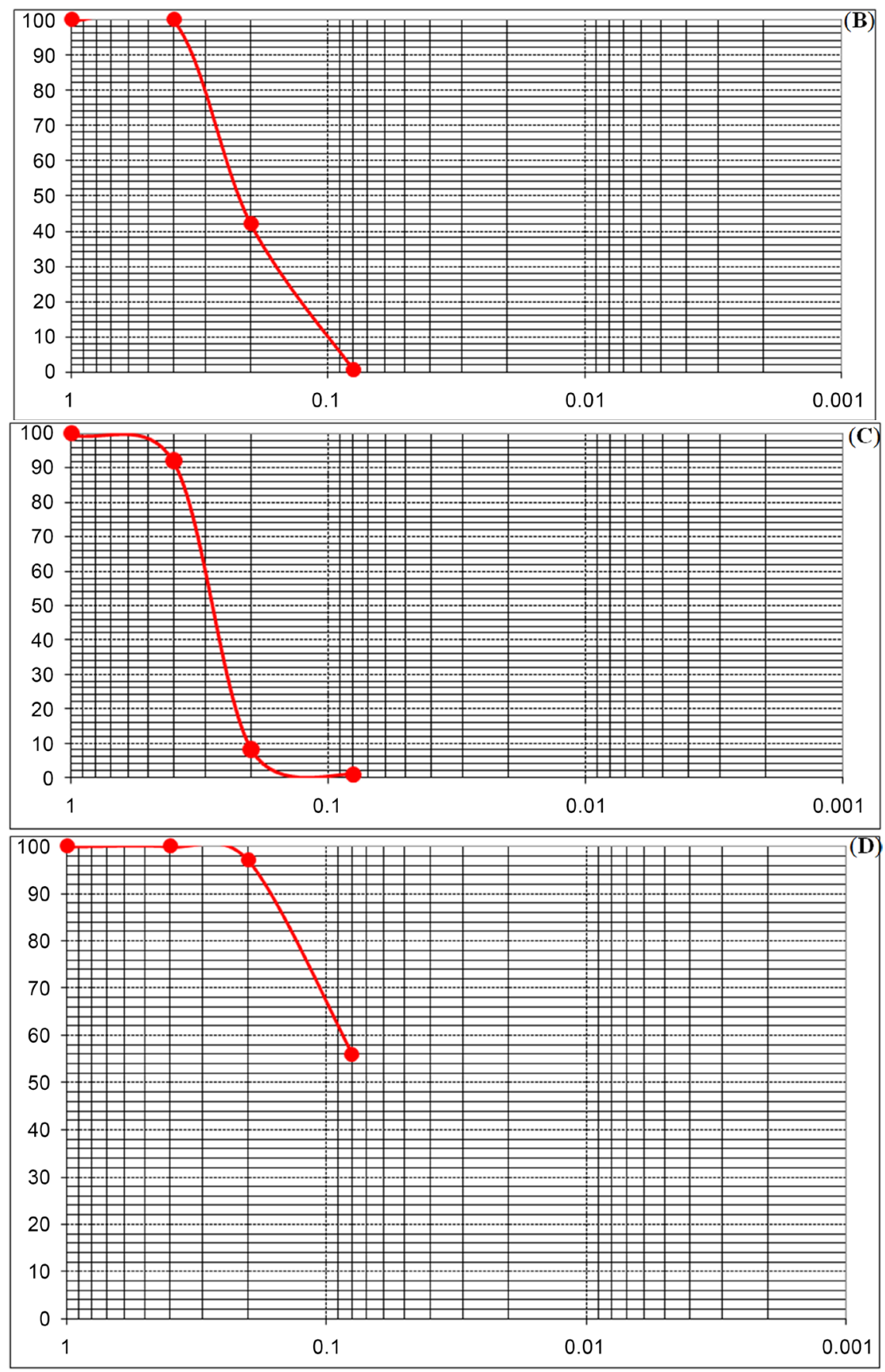

Figure 12. Particle size distribution curves of soil samples from the riverbanks of Stanley Pool Island for: (A) Zone 1 Sample 1; (B) Zone 2 Sample 2; (C) Zone 2 Sample 3 and (D) Zone 3 Sample 4.

The respective particle size curves are shown in the figures below (Figure 12).

\subsection{Atterberg Boundaries}

Landing limits were performed on samples with a Modulus of fineness less than 0.8 from Zone 3 of our study area. Table 1 summarizes the average Atterberg boundary values calculated on the major surface formations in Zone 3. For sim- 
ilar liquidity limits, the sandy clays in sample 4 ( \pm eroded soils) have much higher plasticity limits than the sandy clays in sample 5 (16.6 and 12.7 percent, respectively) resulting in lower PIs than the other (15 percent versus 19 percent). This is because the Atterberg limits define the water content characteristic of certain changes of state and the liquidity limit corresponds in theory to a water content for which the soil has a cohesion identical to that of the interstitial liquid. In practice, humidity is sought which corresponds to the lowest possible cohesion and for which the furrow traced on the wetland surface is erased after a defined number of tremors (Casagrande apparatus) (Mettauer et al., 1983). To do so, a representation of the landingberg limits was schematized in Figure 13 for samples 4 and 5 , and shows that the correlation coefficient values are clearly strong close to 1 .

It can be seen that the materials of these samples are respectively not very plastic and plastic (respectively with an IP of 15\% for sample 4 and 19\% for sample 5).

\subsection{Mechanical Erosion Resistance}

The strength of materials subjected to erosion was determined using the Direct

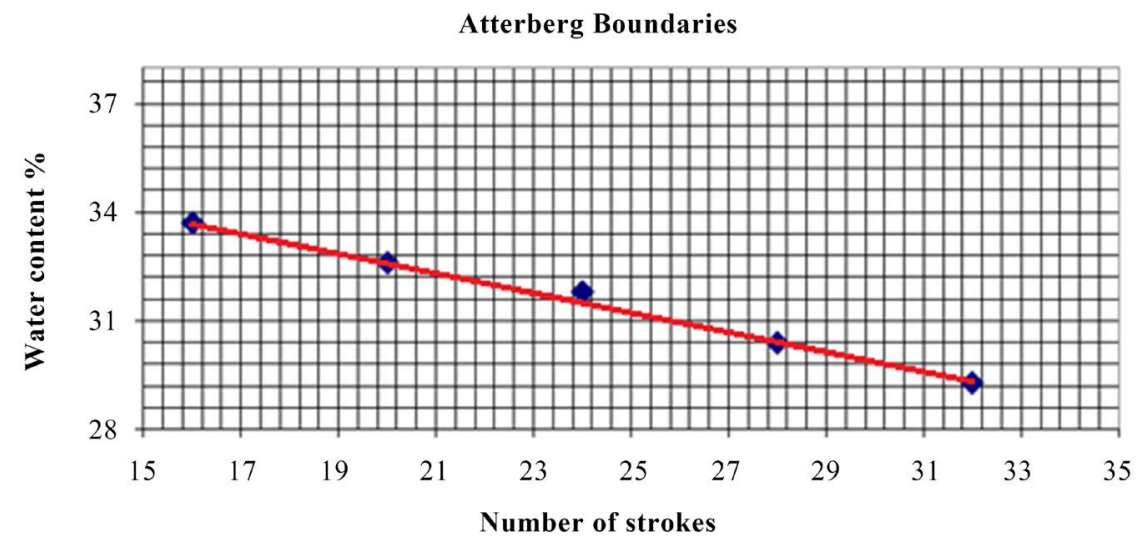

(A)

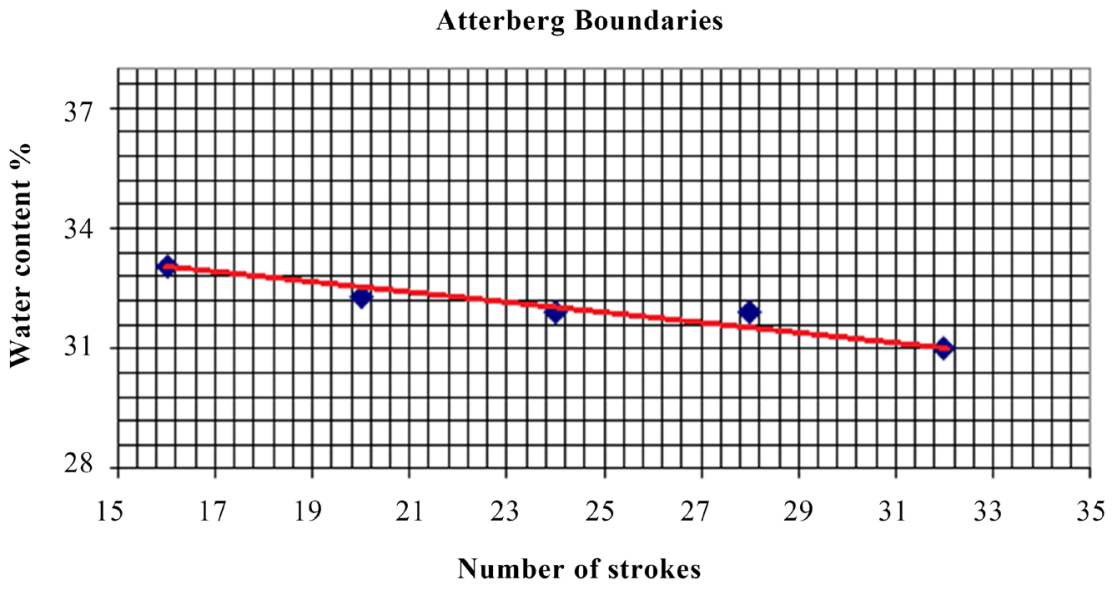

(B)

Figure 13. Atterberg Boundaries Curves: (A) Sample 4 and (B) Sample 5 in zone 3. 
Shear test applied to undisturbed samples (Table 1 ). This test is expressed by the effective cohesion $\left(c^{\prime}\right)$ and the internal friction angle $(\varnothing)$. The results obtained show that sample 4 has a lower effective cohesion than sample 5 while its friction angle is greater than that of sample 5. This cohesion is the force of attraction that unites particles to each other and ensures their physical coherence.

\section{Discussion}

The morpho-sedimentological characteristics of the study area show that several factors of these materials influence riverbank erosion. Depending on these characteristics, the simple presence of water, action of currents or groundwater flow easily destabilize the materials that make up the riverbank and cause the fines to creep (Collapse of sandy riverbanks, Landslide of sandy riverbanks, ...). The riverbank is thus weakened and the work of erosion is differential according to the resistance of the rocks. The structure of the soil, characterized by the arrangement of the aggregates relative to each other, influence the rate of surface runoff and therefore the amount of material displaced; the lower the flow, the lower the number of the roughness in the soil (Wouters \& Wolff, 2010). The texture influences the cohesion of the soil and therefore its resistance to gullying. A clayey soil, for example, has sufficient cohesion, due to its colloidal properties which prevent excessive loss of materials therefore significant runoff (Gaucher, 1968). For this of this study, the analysis presents very low shear strength less than 20 percent (Table 1).

Initial soil moisture determines the amount of precipitated water that can infiltrate through soil components and thus the amount that can run off its surface (Fitzjohn et al., 1998). According to Shainberg et al. (1996), particles in a saturated soil tend to move away from each other, thus limiting their cohesion, whereas a soil with low water content would limit the reorganization of the constituent elements in a position improving their interactions; both cases being favorable to the erosive mechanism. Hanson (in Knapen et al., 2007) there is optimal water content that limits soil sensitivity to the erosive process. Erosion is most likely and shows seasonal variation, occurs preferentially in the high water season (for the Congo River from October to February), when evaporation is low and the soil remains saturated for a long period (Kirkby \& Morgan, 1980; Wouters \& Wolff, 2010). The low-water season is characterized by a predominantly higher infiltration rate and therefore a much lower water content and runoff into the soil (Wei et al., 2007).

However, riverbank erosion processes are complex phenomena. They result from an unfavorable combination of one or more variables linked to the configuration of the riverbank, the greater or lesser participation of the various agents of erosion and human action.

The proximity (about $3 \mathrm{~m}$ of banks) of the navigation channel of the Congo River at the Stanley Pool to the riverbanks is one of the main factors of instability of the latter. 
On the riverbanks of the Congo River at the Stanley Pool, the characteristics and phenomena of the Congo River show plurality of low-water channels meandering within the river bed where the main current is shifted to the outside of the meander and licks successively the right and left riverbanks, describing meanders larger than the axis of the apparent bed (Figure $1(\mathrm{C})$ ).

The zones (meanders), subjected to the highest flow velocities, are the areas with maximum erosion: the concave riverbank deepens while on the convex riverbank, the current is too slow for its load and so abandons part of the load.

\section{Conclusion}

This study highlighted the significant causes of these erosions based on the results of the geotechnical approach (particle size distribution, Atterberg limits and Shear tests); that is, it highlighted the configuration of the riverbanks of the Congo River at the Stanley Pool. Several elements, among many others, the nature of the materials (Fine sands, Sandy clay) that make up the riverbanks, particle size, mixture and arrangement, consistency and cohesion of the soil types (clay, sand, silt, etc.) are elements that promote erosion of the banks of the Congo River at Stanley Pool. These riverbanks are characterized by sandy materials mainly of very fine grains as the fineness modulus (MF) is between 0.97 and 1.99. The smallest dimension of the aggregates is less than $0.5 \mathrm{~mm}$; the classes of sands are $0 / 0.200$ to $0 / 0.5$. The D50 values are $0.130 \mathrm{~mm}, 0.230 \mathrm{~mm}$ and 0.280 $\mathrm{mm}$ respectively. These characteristics of sands in the presence of water weaken the riverbanks and cause erosion.

\section{Conflicts of Interest}

The authors declare no conflicts of interest regarding the publication of this paper.

\section{References}

ASTM D422-63 (2007). Standard Test Method for Particle-Size Analysis of Soils (Withdrawn 2016).

ASTM D4318-00 (2000). Standard Test Methods for Liquid Limit, Plastic Limit and Plasticity Index of Soils (Vol. 4, pp. 1-14). Annual Book of ASTM Standards.

ASTM-D3080 (1998). Standard Test Method for Direct Shear Test of Soils under Consolidated Drained Conditions.

Casagli, N., Rinaldi, M., Gargini, A., \& Curini, A. (1999). Pore Water Pressure and Streambank Stability: Results from a Monitoring Site on the Sieve River, Italy. Earth Surface Processes and Landforms, 24, 1095-1114. https://doi.org/10.1002/(SICI)1096-9837(199911)24:12<1095::AID-ESP37>3.0.CO;2-F

Couper, P. R., \& Maddock, I. P. (2001). Subaerial Riverbank Erosion Processes and Their Interaction with Other Bank Erosion Mechanisms on the River Arrow, Warwickshire, UK. Earth Surface Processes and Landforms, 26, 631-646. https://doi.org/10.1002/esp.212

Dapporto, S., Rinaldi, M., \& Casagli, N. (2001). Failure Mechanisms and Pore Water 
Pressure Conditions: Analysis of a Riverbank along the Arno River (Central Italy). Engineering Geology, 61, 221-242. https://doi.org/10.1016/S0013-7952(01)00026-6

Fitzjohn, C., Ternan, J. L., \& Williams, A. G. (1998). Soil Moisture Variability in Semi-Arid Gully Catchment: Implication for Runoff and Erosion Control. Catena, 32, 55-70. https://doi.org/10.1016/S0341-8162(97)00045-3

Gaillardet, J., Dupré, B., \& Allègre, C. A. (1995). Global Geochemical Mass Budget Applied to the Congo Basin Rivers: Erosion Rates and Continental Crust Composition. Geochimica et Cosmochimica Acta, 59, 3469-3485. https://doi.org/10.1016/0016-7037(95)00230-W

Gaucher, G. (1968). Traité de pédologie agricole: Le sol et ses caractéristiques agronomiques (p. 1). Paris: Dunod.

Hamel, V. B., Buffin-Bélanger, T., \& Hétu, B. (2013). Contribution à l'étude de l'érosion des berges: Analyse à haute résolution spatio-temporelle des mouvements subaériens sur une berge de la rivière Ouelle, Québec, Canada. Géomorphologie: Relief, Processus, Environnement, 19, 119-132. https://doi.org/10.4000/geomorphologie.10176

Kirkby, M. J., \& Morgan, R. P. C. (1980). Soil Erosion. Chichester: John Wiley \& Sons.

Knapen, A., Poesen, J., Govers, G., Gyssels, G., \& Nachtergaele, J. (2007). Resistance of Soils to Concentrated Flow Erosion: Earth-Science Review, 80, 75-109.

https://doi.org/10.1016/j.earscirev.2006.08.001

Laraque, A., Bricquet, J.-P., Pandi, A., \& Olivry, J.-C. (2009). A Review of Material Transport by the Congo River and Its Tributaries. Hydrological Processes, 23, 3216-3224. https://doi.org/10.1002/hyp.7395

Laraque, A., Mahé, G., Orange, D., \& Marieu, B. (2001). Spatiotemporal Variations in Hydrological Regimes within Central Africa during the XXth Century. Journal of Hydrology, 245, 104-117. https://doi.org/10.1016/S0022-1694(01)00340-7

Lawler, D. M. (1992). Process Dominance in Bank Erosion Systems. In P. A. Carling, \& G. E. Petts (Eds.), Lowland Floodplain Rivers Geomorphological Perspectives (pp. 117-143). Chichester: Wiley.

Mettauer, H., Tual, Y., Huck, Ch., \& Trendel, R. (1983). De la connaissance du comportement physique et mecanique des sols de l'Est de la France. Agronomie, EDP Sciences, 3, 141-152. https://doi.org/10.1051/agro:19830205

Moukolo, N., Laraque, A., Olivry, J.-C., \& Bricquet, J.-P. (1993). Transport en solution et en suspension par le fleuve Congo (Zaïre) et ses principaux affluents de la rive droite. Hydrological Sciences Journal, 38, 133-145. https://doi.org/10.1080/02626669309492651

Orange, D., Olivry, J.-C., \& Censier, C. (1995). Variations et bilans de flux de matières particulaires et dissoutes de l'Oubangui à Bangui (de 1987 à 1992). In Grands Bassins Fluviaux Périatlantiques: Congo, Niger, Amazone, Actes du colloque PEGI-INSU-CNRS-ORSTOM (pp. 147-158). Paris: ORSTOM.

Probst, J. L., Nkounkou, R. R., Krempp, G., Bricquet, J.-P., Thiébaux, J.-P., \& Olivry, J.-C. (1992). Dissolved Major Elements Exported by the Congo and the Ubangi Rivers during the Period 1987-1989. Journal of Hydrology, 135, 237-257.

https://doi.org/10.1016/0022-1694(92)90090-I

Shainberg, I., Goldstein, D., \& Levy, G. J. (1996). Rill Erosion Dependence on Soil Water Content Aging, and Temperature. Soil Science Society of America Journal, 60, 916-922. https://doi.org/10.2136/sssaj1996.03615995006000030034x

Thorne, C. R., \& Tovey, N. K. (1981). Stability of Composite Riverbanks. Earth Surface Processes and Landforms, 6, 469-484. https://doi.org/10.1002/esp.3290060507 
Wei, L., Zhang, B., \& Wang, M. (2007). Effects of Antecedent Soil Moisture on Runoff and Soil Erosion in Valley Cropping Systems, Agriculture Water Management, 94, 54-62. https://doi.org/10.1016/j.agwat.2007.08.007

Wood, A. L., Simon, A., Downs, P. W., \& Thorne, C. R. (2001). Bank-Toe Processes in Incised Channels: The Role of Apparent Cohesion in the Entrainment of Failed Bank Materials. Hydrological Processes, 15, 39-61. https://doi.org/10.1002/hyp.151

Wouters, T., \& Wolff, E. (2010). A Contribution to the Analysis of Urban Erosion in Kinshasa (D.R.C.). Belge, 3, 1-24. 